\title{
An Attempt to Increase Numbers of Herbivorous Fishes as a Means of Controlling Populations of Fleshy Macroalgae on Coral Reefs in Kāne'ohe Bay, Hawai ${ }^{i}{ }^{1}$
}

\author{
Eric 7. Conklin ${ }^{2,3}$ and Fobn Stimson ${ }^{3,4}$
}

\begin{abstract}
This study was conducted to determine the feasibility of enhancing fish populations as a means of controlling macroalgal populations in Kāne'ohe Bay, O'ahu, Hawai'i. Fleshy macroalgae have overgrown corals on reef slopes of Kāne'ohe Bay. Such shifts to fleshy macroalgal domination are often thought to be due to a decrease in abundance of herbivorous fishes. This experiment added 650 herbivorous fishes (acanthurids and scarids) to two reefs, constituting a potential addition of approximately $70 \%$ to the total populations of the two reefs. Fish censuses and grazing assays were used to assess the effectiveness of these additions in increasing grazing on these reefs and thereby diminishing the abundance of macroalgae. Fish censuses showed a smaller than expected increase in acanthurid abundance across all reefs, including the control reef, and no increase in scarid abundance. Grazing assays did not show any significant differences between pre- and postaddition. The fishes did not appear to remain on the small isolated reefs to which they were added. It is possible that habitat degradation and lack of shelter on the experimental reefs made them unsuitable for enhanced herbivore populations, because initial and postaddition biomass/ unit area was smaller than the published values for many sites. Increasing the abundance of shelter may be necessary to increase the number of fishes on these reefs.
\end{abstract}

Healthy CORAL ReEF systems are typically dominated by reef-building corals, with nearly all algal production removed by grazers (Carpenter 1986). In areas of anthropogenic influence, however, shifts from coral to macroalgal domination of reefs can occur. These increases in macroalgal abundance, or

\footnotetext{
${ }^{1}$ Funding for this research was provided by National Oceanic and Atmospheric Administration Hawai'i Coral Reef Initiative Research Program Grant no. 655651 awarded to J. Stimson, C. Hunter, C. Smith, and E. Reese. Manuscript accepted 27 May 2003.

${ }^{2}$ Corresponding author: Hawai'i Institute of Marine Biology, P.O. Box 1346, Kāne'ohe, Hawai'i 96744 (phone: 808-236-7439; E-mail: econklin@hawaii.edu).

${ }^{3}$ Department of Zoology, 2538 The Mall, Edmondson Hall, University of Hawai'i at Mānoa, Honolulu, Hawai'i 96822.

${ }^{4}$ Hawai'i Institute of Marine Biology, P.O. Box 1346, Kāne`ohe, Hawai'i 96744.
}

Pacific Science (2004), vol. 58, no. 2:189-200

(C) 2004 by University of Hawai'i Press "phase shifts," can lead to reduced organismal diversity on reefs (McClanahan et al. 1999) and ultimately to the degradation of the physical structure of reefs (Done 1992). Phase shifts have been observed on Caribbean, western Atlantic, western and central Pacific, and Indian Ocean reefs (Done 1992, Littler et al. 1992, Naim 1993, Hughes 1994, Hunter and Evans 1995, Lapointe 1997, McClanahan et al. 1999) and have been attributed to increased anthropogenic nutrient input (Cuet 1988, Littler et al. 1992, Lapointe 1997, 1999), reductions in the abundance of herbivores (Hay 1984, Carpenter 1990, Hughes 1994, Hughes et al. 1999), or coral mortality creating excessive space for algal growth (Williams and Polunin 2001, Williams et al. 2001).

Despite the widespread occurrence of phase shifts and their negative impacts, surprisingly little research has been conducted experimentally testing potential management techniques for remediation of impacted reefs. Nutrient inputs are often difficult to control 
and fishing regulations are politically unfeasible and difficult to enforce in many situations (Bohnsack 1993). McClanahan et al. $(1999,2001)$ suggested that feasible methods to control macroalgal overgrowth of reefs might be to increase rates of grazing, manually remove algae, or decrease nutrient inputs. In some of the only experimental tests of these techniques, McClanahan et al. (1999, 2001) removed all macroalgae from large plots inside a long-established reserve (McClanahan et al. 1999) and both inside and outside reserves (McClanahan et al. 2001) to determine the impact of removal on the local communities and the ability of protected (increased) grazer populations to keep macroalgae out of cleared areas. In these studies, fleshy macroalgae recovered to near preremoval level within several months to $1 \mathrm{yr}$. McClanahan et al. (2001) speculated that it may take a fairly long time for reserves to accumulate the grazer biomass necessary to keep macroalgae from reinvading cleared habitat. However, the recent natural increase of the urchin Diadema antillarum in Jamaica and corresponding decrease in macroalgal cover and increase in juvenile coral abundance (Edmunds and Carpenter 2001) gives credence to the idea that increased herbivore abundance can be an effective remediation technique for reefs that have undergone phase shifts.

In this paper we examine an alternative method to test whether increased grazing can help control macroalgae on algal-dominated reefs-the enhancement of the resident herbivore population of a reef via the addition of herbivorous fishes. Artificial enhancements may be effective means of increasing fish populations limited by extrinsic factors such as recruitment limitation (Doherty and Fowler 1994) or overfishing and potentially could provide a rapid means of achieving sufficient grazer biomass to reduce macroalgal populations.

Kāne'ohe Bay is an appropriate environment in which to test this method, because there has been a well-studied phase shift on the reefs in the bay. Many reef slopes and outer reef flats once covered by hermatypic corals have been overgrown by the native green macroalga Dictyosphaeria cavernosa (Banner and Bailey 1970, Maragos 1972). The initial expansion of $D$. cavernosa on Kāne'ohe Bay reefs is almost certainly the result of nutrient-rich sewage discharge into the bay (Pastorok and Bilyard 1985, Done 1992, Laws 1993, Lapointe 1997), but recent studies have shown that $D$. cavernosa cover remains high and is even increasing, despite the diversion of sewage and decreasing nutrient levels (Hunter and Evans 1995, Stimson and Larned 2000, Stimson et al. 2001; F. Cox and S. Larned, unpubl. data). Current evidence suggests that altered and reduced herbivory may be the cause of the persistence of macroalgal domination (Smith 1993, Stimson et al. 2001), and numerous researchers have suggested that, in general, although nutrients can contribute to phase shifts, low levels of herbivory are essential to algae outcompeting corals on reefs (Hughes et al. 1999, McCook 1999, McCook et al. 2001, Smith et al. 2001, Jompa and McCook 2002).

In this study, we attempted to increase the abundance of herbivorous fishes on two patch reefs in Kāne'ohe Bay overgrown by D. cavernosa to test the feasibility of enhancing herbivore populations as a management tool to remediate the effects of a phase shift to macroalgal domination. Herbivorous fishes were transplanted to experimental reefs while fish densities and the rates of grazing on fleshy macroalgae were being monitored on experimental and control reefs.

\section{MATERIALS AND METHODS}

\section{Study Sites}

The patch reefs used in this study are located in Kāne'ohe Bay, Hawai' $i$, a partially enclosed embayment, $46 \mathrm{~km}^{2}$ in area, on the windward side of the island of O'ahu, Hawai'i (Figure 1). The bay has approximately 70 patch reefs scattered throughout its length, of various sizes from reefs $\approx 50 \mathrm{~m}$ in circumference to those over $1 \mathrm{~km}$. The bay is mostly protected from oceanic swells by an extensive barrier reef and a large peninsula. 


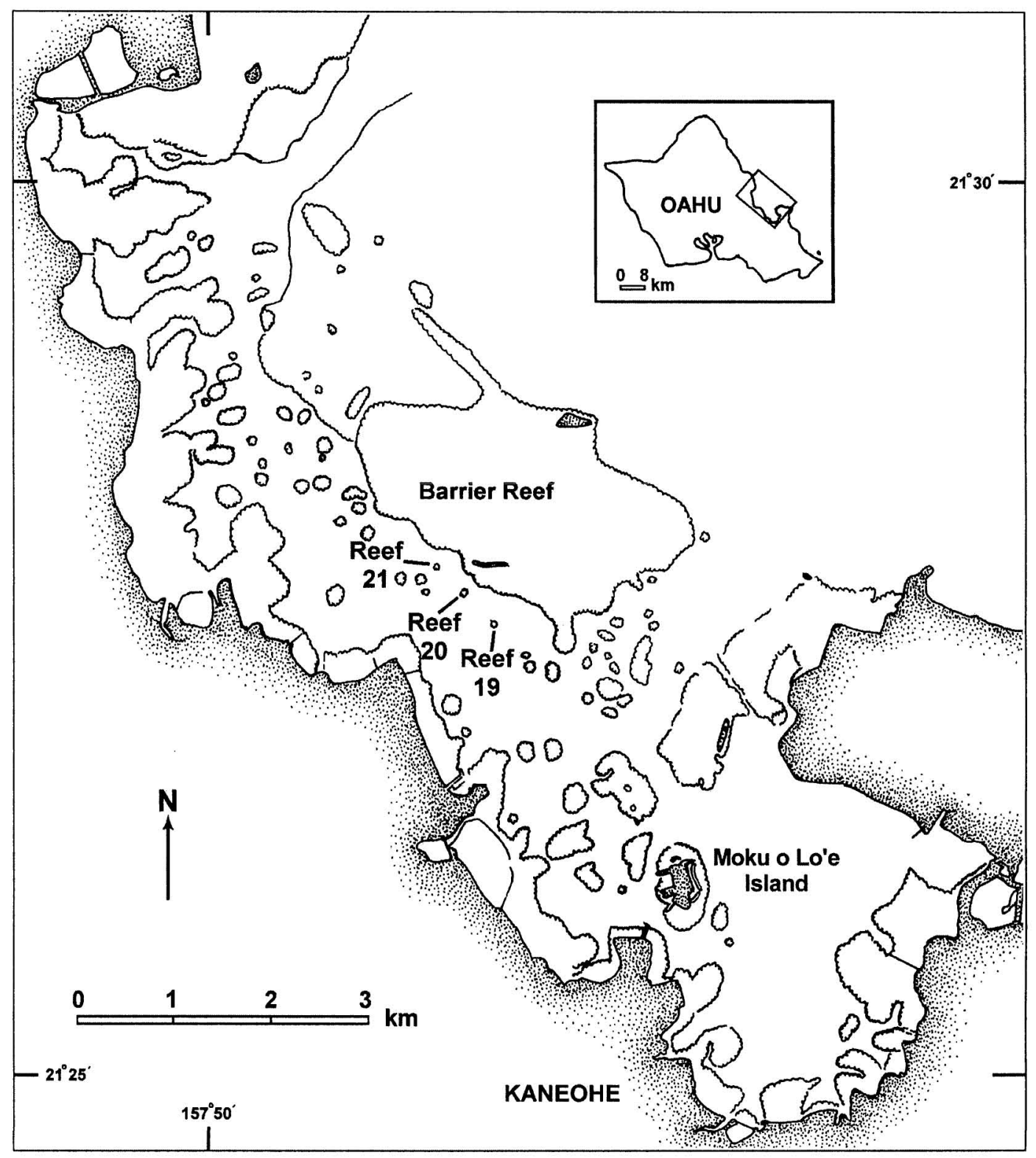

FIGURE 1. Map of Kāne'ohe Bay, showing the location of the three reefs: experimental reefs 19 and 20 and control reef 21 .

Three reefs were utilized in this study, with reefs 19 and 20 randomly assigned to the experimental treatment to which herbivorous fishes were added and reef 21 serving as a control (Roy 1970) (Figure 1). These three reefs were chosen for two reasons. First, their small size (circumferences: reef 19, $114 \mathrm{~m}$; reef $20,144 \mathrm{~m}$; and reef $21,89 \mathrm{~m}$ ) and subsequent small herbivore populations made it feasible to add a proportionately large num- 
ber of herbivorous fishes to these reefs. Second, fishes transplanted to these reefs would have to travel $>100 \mathrm{~m}$ over the relatively deep $(\approx 15 \mathrm{~m})$, featureless (fine sediment) lagoon floor to reach the nearest neighboring reef, which we hoped would minimize the chances that transplanted fishes would emigrate from the reefs to which they were added. These two constraints on reef selection, for small size and isolated location, left us with little replication in our experimental treatments and none in our control.

The reefs are characterized by abundant macroalgae on the reef slopes, with Dictyosphaeria cavernosa accounting for 62,60 , and $34 \%$ of the benthic cover between $1-\mathrm{m}$ and $5-\mathrm{m}$ depth on the reef slopes of reefs 19, 20, and 21, respectively (E.J.C., unpubl. data), and small reef flats dominated by fleshy macroalgae and crustose coralline algae. The most abundant herbivores are juvenile scarids (Scarus spp.), with smaller numbers of the acanthurids Acantburus blochii, $A$. triostegus, $A$. nigrofuscus, Ctenochaetus strigosus, Zebrasoma flavescens, and $Z$. velifrum.

\section{Herbivorous Fish Additions}

Herbivorous fishes were transplanted to the experimental reefs from August 1999 through December 1999. The added fishes were trapped on several larger patch reefs in Kāne'ohe Bay in 1 by 0.5 by $0.25 \mathrm{~m}$ fish traps made of hardware cloth. Herbivorous fishes found in these traps were removed from the traps and placed in a large holding tank for immediate transport via small boat to the experimental reefs. Before release of the transplanted fishes, the standard lengths of a random subsample of fishes were recorded. In addition, most of the scarids were tagged with an elastomer dye (Visual Implant Elastomer from Northwest Marine Technologies) that can be used for in situ identification of tagged fish (Frederick 1997). Tags were used to determine whether transplanted fishes were remaining on the reefs to which they had been added or were leaving for nearby reefs or their "home" reefs. The tagging procedure involved first anesthetizing the fish in $0.25 \mathrm{~g}$ MS-222 (tricaine methane sulfonate)/liter seawater, injecting ca. $0.01 \mathrm{ml}$ of dye underneath a scale on either side of the fish, and then recovering the fish in seawater. These tags were bright orange and easily visible in the field. After measuring and tagging, fishes were placed on the experimental reefs in 1 by 0.5 by $0.25 \mathrm{~m}$ holding cages made of hardware cloth to allow fishes to become accustomed to the experimental reef. The cages were stocked with abundant macroalgae to provide food for the fishes. After 1 to 7 days of acclimatizing to the reef, the fishes were released. Haphazard surveys for tagged individuals were conducted throughout the duration of the experiment on the experimental and control reefs, as well as the neighboring reefs and the "home" reefs from which the fishes were removed.

\section{Effectiveness of Fish Tagging}

To determine how long tags were retained by scarids and the impact the tagging procedure has on behavior and site fidelity, retention and site fidelity studies were conducted on Moku o Lo'e Island (Hawai'i Institute of Marine Biology) (Figure 1). For the retention study, 16 scarids were trapped on the reef flats of Moku o Lo'e Island in February 2002. Each fish was then injected (following procedures described in the preceding section) with a unique code of six to seven tags and placed in pens constructed of polyvinyl chloride (PVC) and Vexar that were suspended from the docks of the Hawai'i Institute of Marine Biology (HIMB). Tagged fishes were then observed periodically (initially every 2 days, then at increasing intervals), with the presence or absence of tags recorded.

To determine whether fishes tagged and returned to the reef at the site of capture would remain near the site of capture, 78 Scarus psittacus were trapped on the reef flat of Moku o Lo'e in March and April 2002, tagged with a unique code as just described, and immediately released at the site of capture. Tagged fish were resighted via visual transects through the area of release conducted between 12 March 2002 and 24 April 2002. When a tagged fish was seen, the code was recorded, and a marker was dropped at 
the location of the resighting. The position of the fish on the reef was then mapped relative to the site of capture.

\section{Fish Surveys of Experimental and Control Reefs}

Visual transect surveys were used to estimate the population densities of herbivorous fishes before and after fishes were added to the experimental reefs. The small size of these reefs allowed the entire perimeter of the reef to be swum as a single transect. The species and approximate size of all herbivorous fishes seen from the reef crest to an estimated $5 \mathrm{~m}$ down the reef slope were recorded. Herbivore density was calculated by dividing the total number of fishes seen on a transect by the circumference of the reef multiplied by the width of the transect. Three replicate transects were swum on each reef each time fishes were censused. All three reefs were surveyed each survey day to reduce variability between reefs in counts due to changes in visibility or the impact of the weather on the behavior of the fish. Preaddition fish surveys were conducted on 16 July 1999, 17 July 1999, 3 August 1999, and 14 August 1999, and postaddition surveys were conducted on 10 January 2000 and 14 January 2000.

Data were analyzed using a modified BACI design (Underwood 1994, E. P. Smith 2002). Two three-way analyses of variance (ANOVAs) were conducted comparing reef 19 and reef 20, respectively, with the control reef 21 , with factors treatment (addition/control), time period (before/after addition), sampling date (random, nested with time period), and the interaction treatment $\times$ time period and treatment $\times$ sampling date (time period). In this model, the significant effect of the herbivore additions would be manifested in a significant interaction between treatment and time period.

\section{Grazing Intensity Assays}

Grazing assays were used to compare the rate of algal biomass removal on each of the three reefs before and after manipulating fish densities. Gracilaria salicornia thalli were collected from the field and cleaned of epiphytic in- vertebrates and filamentous algae. Thalli were then weighed (wet weights after being spun in a salad spinner to remove excess water) and placed in individual clothespin holders (Lewis and Wainwright 1985); thalli weighed 1.000 $1.400 \mathrm{~g}$ wet weight. Thalli were placed at each of two sites on each of the three reefs on the reef crest and slope at 2-m depth for $48 \mathrm{hr}$, six thalli in grazer-exclusion cages and 10 thalli exposed to grazers. Growth rates were calculated from the weight changes and elapsed time ( $g$ weight change $\cdot \mathrm{g}^{-1}$ initial weight $\cdot$ day $\left.^{-1}\right)$. Grazing intensity was measured as the difference between the growth of caged and uncaged thalli. Three replicate runs of the $G$. salicornia assays were performed both before (starting on 15 July 1999 , 20 July 1999, 1 September 1999) and after (starting on 13 December 1999, 1 January 2000, 12 January 2000) adding herbivorous fishes (total $n=36$ caged and 60 uncaged thalli per reef, both before and after transplants). $\log (x+1)$-transformed data were analyzed with three-way ANOVAs with the factors treatment (addition/control), time period (before/after addition), and replicate run (random, nested with time period), with the interaction treatment $x$ time period being the test of significant addition effects.

\section{RESULTS}

\section{Fish Censuses and Transplants}

Between August and December 1999, a total of 282 herbivorous fishes was transplanted to reef 19 , and 368 were transplanted onto reef 20 (Tables 1 and 2). For both reefs, ca. 75\% of the fishes transplanted were juvenile scarids, with the remaining $25 \%$ comprising several species of acanthurids. The average lengths of the fishes transplanted to the two reefs were similar (Table 2); almost all fishes transplanted were small (ca. $10 \mathrm{~cm} \mathrm{SL}$ ) but similar in size to the resident populations. Acanthurids and scarids of these sizes have been observed to feed extensively on fleshy macroalgae, including $D$. cavernosa and $G$. salicornia (E.J.C., pers. obs.). Although almost 100 more fishes were transplanted to reef 20 than to reef 19 , the numbers are fairly even 
TABLE 1

Time Course of Additions of Acanthurids and Scarids to Experimental Reefs

\begin{tabular}{|c|c|c|c|}
\hline Reef 19 & $\begin{array}{l}\text { No. of Fish } \\
\text { Transplanted }\end{array}$ & Reef 20 & $\begin{array}{l}\text { No. of Fish } \\
\text { Transplanted }\end{array}$ \\
\hline 21 Aug. 1999 & 47 & 28 Aug. 1999 & 34 \\
\hline 04 Sept. 1999 & 30 & 11 Sept. 1999 & 26 \\
\hline 12 Sept. 1999 & 6 & 06 Oct. 1999 & 12 \\
\hline 18 Sept. 1999 & 12 & 09 Oct. 1999 & 8 \\
\hline 16 Oct. 1999 & 52 & 10 Oct. 1999 & 18 \\
\hline 22 Oct. 1999 & 98 & 22 Oct. 1999 & 106 \\
\hline 29 Oct. 1999 & 13 & 05 Nov. 1999 & 12 \\
\hline 06 Nov. 1999 & 11 & 27 Nov. 1999 & 74 \\
\hline 12 Nov. 1999 & 3 & 3 Dec. 1999 & 40 \\
\hline \multirow[t]{3}{*}{20 Nov. 1999} & 10 & 4 Dec. 1999 & 4 \\
\hline & & 11 Dec. 1999 & 3 \\
\hline & & 13 Dec. 1999 & 31 \\
\hline Total & 282 & Total & 368 \\
\hline
\end{tabular}

TABLE 2

Total Number of Each Species of Fish Transplanted to Experimental Reefs from August through December 1999 and the Average Standard Length ( $\mathrm{cm} \pm 1 \mathrm{SD}$ ) for Each Species

\begin{tabular}{|c|c|c|c|c|}
\hline \multirow[b]{2}{*}{ Species } & \multicolumn{2}{|c|}{ Reef 19} & \multicolumn{2}{|c|}{ Reef 20} \\
\hline & No. Added & Std Length & No. Added & Std Length \\
\hline Scarus spp. & 218 & $7.5 \pm 1.5$ & 274 & $7.7 \pm 1.6$ \\
\hline Acanthurus blochii & 39 & $11.7 \pm 1.2$ & 36 & $12.1 \pm 0.9$ \\
\hline A. triostegus & 11 & $7.7 \pm 2.1$ & 40 & $7.9 \pm 1.5$ \\
\hline A. nigrofuscus & 0 & & 3 & \\
\hline Ctenochaetus strigosus & 2 & $11.8 \pm 1.0$ & 3 & 12 \\
\hline Zebrasoma flavescens & 11 & $9.0 \pm 2.9$ & 7 & $9.7 \pm 0.9$ \\
\hline Z. velifrum & 1 & & 5 & $10.2 \pm 2.5$ \\
\hline Total & 282 & & 368 & \\
\hline
\end{tabular}

if standardized to the size of the reef: reef 19 received 2.5 fishes $\mathrm{m}^{-1}$ perimeter $(282$ fishes . $114 \mathrm{~m}^{-1}$ perimeter), and reef 20 received 2.6 fishes $\mathrm{m}^{-1}$ perimeter ( 368 fishes $\cdot 144 \mathrm{~m}^{-1}$ ). The average numbers of herbivorous fishes counted in the fish surveys before the additions were $198( \pm 43 \mathrm{SD}, n=12)$ and 380 $( \pm 56 \mathrm{SD}, n=12)$ for reefs 19 and 20 , respectively. Brock (1979) working on reef 21 determined that fish surveys count ca. $60 \%$ of the total number of fishes that are on a reef at a given time. Therefore, if the true population sizes of these reefs are ca. 330 fishes for reef 19 and 633 fishes for reef 20, then our additions added $85 \%$ and $58 \%$ to the total populations of reefs 19 and 20, respectively.

These additions, however, did not significantly increase the abundance of herbivorous fishes on the experimental reefs relative to the control reef according to an ANOVA analysis. The analysis did, however, show that acanthurids were significantly more abundant across all reefs following the herbivore additions (reef 19 versus reef 21, before/after addition, $F=9.87$; $\mathrm{df}=1,4 ; P=0.035$; reef 20 versus reef 21 , before/after addition, $F=$ $14.39 ; \quad \mathrm{df}=1,4 ; \quad P=0.019$ ) (Figure $2 A$ ). However, the interaction between before/ 

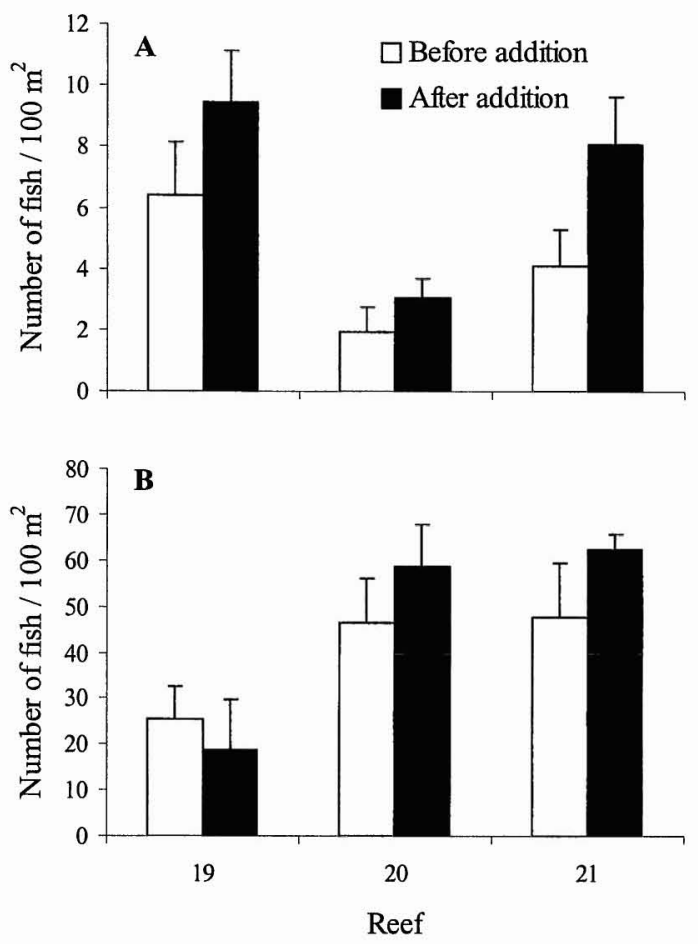

FIgURE 2. Mean number of individuals per $100 \mathrm{~m}^{2}$ for acanthurids $(A)$ and scarids $(B)$ on experimental reefs 19 and 20 and control reef 21 before and after addition of herbivorous fishes to the experimental reefs. Error bars indicate +1 SD.

after and treatment tests the impact of the additions and was not significant between reefs 19 and 21 (three-factor ANOVA; $F=0.048$; $\mathrm{df}=1,4 ; P=0.527)$ and significant between reefs 20 and $21(F=17.73 ; \mathrm{df}=1,4 ; P=$ $0.014)$ in the opposite direction of that expected, with a significantly greater increase of acanthurids on the control reef 21 . ANOVA analyses of scarid densities (Figure $2 B$ ) indicated no significant increase in scarids on experimental reefs relative to the control (reef 19 versus reef 21 , before/after addition, $F=$ $0.65 ; \mathrm{df}=1,4 ; P=0.465$; reef 20 versus reef 21 , before/after addition, $F=3.13$; $\mathrm{df}=1,4$; $P=0.152)$ and no significant interactions between before/after and treatment (reefs 19 and $21, F=2.07 ; \mathrm{df}=1,4 ; P=0.223$; reefs 20 and $21, F=0.07$; df $=1,4 ; P=0.804$ ).
Fish surveys conducted after additions revealed that some tagged fishes did remain on the reefs, because tagged individuals were seen mixed into schools of resident fishes at least a week after being released. However, their relative abundance was much lower than expected based on the number of transplants relative to the number of resident fishes estimated to be on the reefs, with only 5-10 individuals seen per census on each reef. No tagged fishes were ever seen on reefs near the experimental reefs (including on the control reef), nor were any ever recaptured on the reefs from which they were removed despite intensive trapping that continued after the transplants.

\section{Effectiveness of Fish Tagging}

A total of 16 scarids (15 Scarus psittacus and 1 Cblororus sordidus) was tagged for the tag retention study between 11 and 22 February 2002 with a total of 97 individual tags. Tag loss was low within the first several days and then increased gradually until the end of the study. On the last survey date, 17 May 2002, 95 days after the first tagging, almost half (47.4\%) of the tags still remained; $18 \%$ of the tags were still present 10 months after injection. The mean length of time that a tag was retained was $59 \pm 3.2$ (SE) days (median = 71 days).

Of the $78 \mathrm{~S}$. psittacus individually tagged and immediately released at their site of capture on Moku o Lo'e Island, 69 were subsequently resighted over a 51-day period. There was a total of 622 separate resightings of tagged fishes, with the number of resightings per individual ranging from 1 to 25 . The dispersal distance (distance from the trap in which the fish was trapped to the location of the resighting) ranged from 1.9 to $45.8 \mathrm{~m}$, with no trend with dispersal distance and the number of days at liberty, with a least-squares regression analysis yielding $P=0.8, r^{2}=0.0$.

\section{Grazing Assays}

Grazing on G. salicornia (Figure 3) was not significantly altered on reef 19 relative to control reef 21 (interaction between treat- 


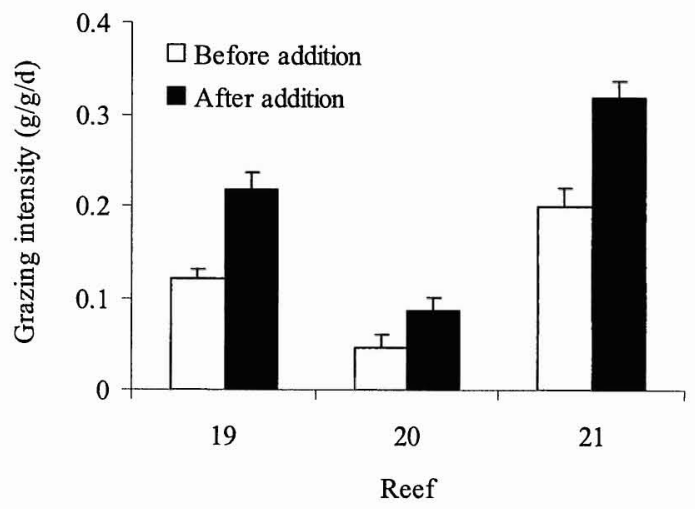

Figure 3. Mean grazing intensity (g algae consumed, g initial weight ${ }^{-1}$, day $^{-1}$ ) on $G$. salicornia before and after the addition of herbivorous fishes. Each bar represents the mean of three separate runs of the grazing assay, each with 20 replicates. Error bars indicate $+1 \mathrm{SE}$.

ment and before/after addition in three-way ANOVA: $F=0.25$; $\mathrm{df}=1,229 ; P=0.616)$. There was a significant interaction between reefs 20 and $21(F=5.16 ; \mathrm{df}=1,229 ; P=$ $0.0246)$, but the difference was in the opposite direction of that expected, with a significantly greater increase in grazing on the control reef 21 following addition of fishes to the experimental reefs.

\section{DISCUSSION}

We were not able to significantly increase the herbivorous fish numbers on the experimental reefs relative to the control, and as a result we could not test the hypothesis that artificially enhancing herbivore populations may be a means of controlling populations of fleshy macroalgae. Although we added fishes sufficient to increase the herbivore populations by ca. $70 \%$ on both reefs, there was no change in scarid abundances, and the abundances of acanthurids on the two experimental reefs did not become greater than that on the control (Figure $2 A$ and $B$ ). Transplanted acanthurids may have emigrated from the addition reefs to the control and other nearby reefs, enhancing overall densities. Because acanthurids were not tagged, we cannot determine whether this occurred or whether increased acanthurid densities were due to natural seasonal variations. Comparisons of our fish censuses with long-term fish censuses on these same reefs indicate that the time period of our fish transplants (August through December) is a time when acanthurid biomass typically increases (J.S., unpubl. data). In fact, the increase in acanthurid numbers that we measured on all three reefs was less than the increase often seen in "good" years when the reefs are unmanipulated.

Regardless of the cause, reefs 19 and 21 both experienced significant increases in acanthurid abundance and also showed increased grazing rates on $G$. salicornia assays (Figures $2 B$ and 3 ). This result suggests that if herbivore populations were to be substantially enhanced over the long term, significant increases in grazing pressure could be achieved. Whether this increase in grazer abundance would be sufficient to decrease fleshy macroalgal abundance remains to be tested.

The lack of a targeted response of the herbivore densities to the additions is surprising, because several lines of evidence suggest that such a manipulation should be feasible. Data on the foraging patterns of both acanthurids and juvenile scarids in Kāne'ohe Bay indicate that these fishes are foraging over relatively small spatial scales $\left(\leq 100 \mathrm{~m}^{2}\right.$ on average [L. Iwahara, pers. comm.; E.J.C., unpubl. data]), which should easily be encompassed within the area of these small patch reefs. The tagand-release study we conducted with juvenile $S$. psittacus on Moku o Lo'e found that the farthest any of the 69 resighted fishes traveled from the site of release was $45.8 \mathrm{~m}$ after 51 days, and the regression analysis demonstrates that they were not dispersing over time.

In addition, mortality due to the transplant process was low, and direct observations of the fishes as they were released from the pens showed that the majority of fishes immediately took shelter on the reef near the holding pen, with many feeding within minutes of release (Acanthurus blocbii and Z. flavescens were exceptions to this rule, with many individuals swimming rapidly away from the trap following release). Several tagged scarids were indeed seen on the addition reefs at least a week after being released feeding in schools 
of unmarked scarids. The number of these tagged individuals seen was not large, however, with only 5 to 10 individuals seen per census on each reef. Given the hundreds of scarids tagged and the mean tag retention time of 59 days, it can only be concluded that many tagged fishes were no longer on the reef at the time of the censuses.

It is not possible to determine whether the loss of transplanted individuals from the experimental reefs was due to emigration from the reef or mortality. There is no direct evidence for emigration, because no tagged scarids were ever observed on the neighboring reefs, including the control reef 21 , nor were any scarids ever found back on the reefs from which they were transplanted, despite extensive trapping and surveying at those sites. The distance between patch reefs was expected to act as a barrier to dispersal, because fishes would have to travel through exposed habitat (i.e., the lagoon floor) to reach adjacent reefs. However, some limited evidence suggests that at least some fish do make these migrations. Brock (1979) found that small acanthurids and scarids that migrated from adjacent patch reefs repopulated a defaunated patch reef in Kāne'ohe Bay. In addition, small schools of juvenile scarids have been seen on rare occasions swimming in open water between the patch reefs in the bay (Reese, as cited in Brock 1979). Ogden and Buckman (1973) transplanted individual scarids, Scarus croicensis, $100 \mathrm{~m}$ from their home reefs in the Caribbean and monitored their behavior. Most returned within 1 day to their home reefs, despite having to cross an extensive sea-grass bed.

Heavy predation rates could also account for some of the loss of transplanted fishes. No attempt was made to quantify the abundance of predators, but numerous predatory fistulariids (cornerfish) were seen on the experimental reefs, and moray eels are known to be abundant on reefs in Kāne'ohe Bay (Stimson et al. 1982). In addition, transient predators such as large carangids (jacks) may temporarily aggregate to reefs with enhanced fish populations but are extremely difficult to monitor. If loss due to predation constrained the effectiveness of the transplants, it may have been preferable to add all the fishes in a single, discrete event to swamp predators. However, the relative merits of predator swamping versus adding small quantities of fishes that can assimilate into the reef community are unknown and would require empirical testing.

Lack of sufficient shelter sites may have contributed to mortality due to predation on the transplanted fish or forced emigration. There is a well-established positive relationship between the abundance of shelter and the abundance of many reef fish (Friedlander and Parrish 1998, Steele 1999), and Brock (1979) proposed that one consequence of heavy algal growth on the patch reefs in the bay is that coral cover is diminished and hence the shelter provided by the coral for fishes is lost. Heavily degraded reefs may simply not have sufficient shelter sites to sustain large herbivore populations, and our transplanted fishes may have represented a surplus population unable to find shelter and therefore susceptible to predation. Large scarids and acanthurids are rare at these sites, possibly lending support to the argument that shelter sites are limiting on these reefs, although their absence could be attributable to fishing pressure, because fishers have been observed spearfishing on these reefs on numerous occasions. If shelter sites are indeed limiting at heavily degraded sites, then a positive feedback system may be in effect where lack of shelter leads to fewer fishes, which leads to more algae being able to persist, which in turn leads to less coral and shelter for fishes. This would correspond with recent research suggesting that there is a threshold abundance of algae on reefs above which herbivorous fishes will be unable to control algal populations (Williams and Polunin 2001, Williams et al. 2001).

The negative relationship between abundance of herbivores and algal abundance is well established (Hay 1981, 1985, Lewis and Wainwright 1985, Lewis 1986, McCook 1996, 1997), and artificially increasing the abundance of herbivores may still be an effective tool for controlling algal expansion and remediating impacted areas. However, this study suggests that simply adding herbivorous fishes to a heavily degraded reef may 
not achieve increased herbivore abundance. The effect of emigration on the effectiveness of transplanting herbivores is still unknown but may be addressed by a more extensive and effective study of tagged fishes. The effect of predation may be large, but could potentially be mediated by either the removal of predators or the addition of shelter sites to reefs. Hixon and Carr (1997) demonstrated that removing predators can have a large impact on fish populations, and adding shelter to low-relief areas has also been shown to be effective in increasing the numbers of herbivorous fish (Randall 1965). Introducing a lessmobile herbivore that is not as dependent on shelter and is less able to disperse, such as sea urchins, could also be effective.

\section{ACKNOWLEDGMENTS}

We thank J. Lopez and J. Tateishi for their considerable help in the field and T. Yoshikawa for assistance with fish tagging. We also thank C. Hunter for logistical support and K. Ikemoto and anonymous reviewers for improving the manuscript. The Hawai' $i$ Institute of Marine Biology provided facilities.

\section{Literature Cited}

Banner, A. H., and J. Bailey. 1970. The effects of urban pollution upon a coral reef system, a preliminary report. Hawai'i Inst. Mar. Biol. Tech. Rep. 50.

Bohnsack, J. A. 1993. Marine reserves: They enhance fisheries, reduce conflicts, and protect resources. Oceanus 36:63-71.

Brock, R. E. 1979. Stability and structure of a fish community on a coral patch reef in Hawaii. Mar. Biol. (Berl.) 54:281-292.

Carpenter, R. C. 1986. Partitioning herbivory and its effects on coral reef algal communities. Ecol. Monogr. 56:345-363.

- 1990. Mass mortality of Diadema antillarum I. Long-term effects on sea urchin population-dynamics and coral reef algal communities. Mar. Biol. (Berl.) 104:6777.

Cuet, P., O. Naim, G. Faure, and J. Y. Conan. 1988. Nutrient-rich groundwater impact on benthic communities of La Sa- line fringing reef (Réunion Island, Indian Ocean): Preliminary results. Proc. 6th Int. Coral Reef Symp. 2:207-212.

Doherty, P., and T. Fowler. 1994. An empirical test of recruitment limitation in a coral reef fish. Science (Washington, D.C.) 263: 935-939.

Done, T. J. 1992. Phase shifts in coral reef communities and their ecological significance. Hydrobiologia 247:121-132.

Edmunds, P. J., and R. C. Carpenter. 2001. Recovery of Diadema antillarum reduces macroalgal cover and increases abundance of juvenile corals on a Caribbean reef. Proc. Natl. Acad. Sci. U.S.A. 98:50675071.

Frederick, J. L. 1997. Evaluation of fluorescent elastomer injection as a method of marking small fish. Bull. Mar. Sci. 61:399_ 408.

Friedlander, A. M., and J. D. Parrish. 1998. Habitat characteristics affecting fish assemblages on a Hawaiian coral reef. J. Exp. Mar. Biol. Ecol. 224:1-30.

Hay, M. E. 1981. Herbivory, algal distribution, and the maintenance of betweenhabitat diversity on a tropical fringing reef. Am. Nat. 118:520-540.

- 1984. Predictable spatial escapes from herbivory: How do these affect the evolution of herbivore resistance in tropical marine communities? Oecologia (Berl.) 64:396-407.

- 1985. Spatial patterns of herbivore impact and their importance in maintaining algal species richness. Proc. 5th Int. Coral Reef Symp. 4:29-34.

Hixon, M. A., and M. H. Carr. 1997. Synergistic predation, density dependence, and population regulation in marine fish. Science (Washington, D.C.) 277:946-949.

Hughes, T. P. 1994. Catastrophes, phase shifts, and large-scale degradation of a Caribbean coral reef. Science (Washington, D.C.) 265:1547-1551.

Hughes, T., A. M. Szmant, R. Steneck, R. Carpenter, and S. Miller. 1999. Algal blooms on coral reefs: What are the causes? Limnol. Oceanogr. 44:1583-1586.

Hunter, C. L., and C. W. Evans. 1995. Coral reefs in Kaneohe Bay, Hawaii: Two cen- 
turies of Western influence and two decades of data. Bull. Mar. Sci. 57:501-515.

Jompa, J., and L. J. McCook. 2002. Effects of competition and herbivory on interactions between a hard coral and a brown alga. J. Exp. Mar. Biol. Ecol. 271:25-39.

Lapointe, B. E. 1997. Nutrient thresholds for eutrophication and macroalgal blooms on coral reefs in Jamaica and Southeast Florida. Limnol. Oceanogr. 42:1119-1131.

- 1999. Simultaneous top-down and bottom-up forces control macroalgal blooms on coral reefs. Limnol. Oceanogr. 44:1586-1592.

Laws, E. A. 1993. Aquatic pollution: An introductory text. 2nd ed. John Wiley \& Sons, New York.

Lewis, S. M. 1986. The role of herbivorous fish in the organization of a Caribbean reef community. Ecol. Monogr. 56:183-200.

Lewis, S. M., and P. C. Wainwright. 1985. Herbivore abundance and grazing intensity on a Caribbean coral reef. J. Exp. Mar. Biol. Ecol. 87:215-228.

Littler, M. M., D. S. Littler, and B. E. Lapointe. 1992. Modification of tropical reef community structure due to cultural eutrophication: The southwest coast of Martinique. Proc. 7th Int. Coral Reef Symp. $1: 335-343$.

Maragos, J. E. 1972. A study of the ecology of Hawaiian corals. Ph.D. diss., University of Hawai'i at Mānoa, Honolulu.

McClanahan, T. R., V. Hendrick, M. J. Rodrigues, and N. V. C. Polunin. 1999. Varying responses of herbivorous and invertebrate-feeding fish to macroalgal reduction on a coral reef. Coral Reefs 18:95203.

McClanahan, T. R., M. McField, M. Huitric, K. Bergman, E. Sala, M. Nyström, I. Nordemar, T. ElfWing, and N. A. Muthiga. 2001. Responses of algae, corals and fish to the reduction of macroalgae in fished and unfished patch reefs of Glovers Reef Atoll, Belize. Coral Reefs 19:367-379.

McCook, L. J. 1996. Effects of herbivores and water quality on Sargassum distribution on the central Great Barrier Reef: Cross-shelf transplants. Mar. Ecol. Prog. Ser. 139: 179-192.
1997. Effects of herbivory on zonation of Sargassum spp. within fringing reefs of the central Great Barrier Reef. Mar. Biol. (Berl.) 129:713-722.

1999. Macroalgae, nutrients and phase shifts on coral reefs: Scientific issues and management consequences for the Great Barrier Reef. Coral Reefs 18:357367.

McCook, L. J., J. Jompa, and G. Diaz-Pulido. 2001. Competition between corals and algae on coral reefs: A review of evidence and mechanisms. Coral Reefs 19:400-417.

Naim, O. 1993. Seasonal responses of a fringing reef community to eutrophication (Réunion Island, Western Indian Ocean). Mar. Ecol. Prog. Ser. 99:137-151.

Ogden, J. C., and N. S. Buckman. 1973. Movements, foraging groups, and diurnal migrations of the striped parrotfish Scarus croicensis Bloch (Scaridae). Ecology 54: 589-596.

Pastorok, R. A., and G. R. Bilyard. 1985. Effects of sewage pollution on coral-reef communities. Mar. Ecol. Prog. Ser. 21: 175-189.

Randall, J. E. 1965. Grazing effect on sea grasses by herbivorous reef fish in the West Indies. Ecology 46:255-260.

Roy, K. J. 1970. Changes in bathymetric configuration, Kaneohe Bay, 1889-1969. Sea Grant Report, University of Hawai' $i$ TR 70-6.

Smith, E. P. 2002. BACI design. Pages 141148 in A. H. El-Shaarawi and W. W. Piegorsch, eds. Encyclopedia of environmetrics. Vol. 1. John Wiley \& Sons, Ltd., Chichester.

Smith, J. E., C. M. Smith, and C. L. Hunter. 2001. An experimental analysis of the effects of herbivory and nutrient enrichment on the benthic community composition of a Hawaiian reef. Coral Reefs 19:332342.

Smith, M. K. 1993. An ecological perspective on inshore fisheries in the main Hawaiian Islands. Mar. Fish Rev. 55:34-49.

Steele, M. A. 1999. Effects of shelter and predators on reef fish. J. Exp. Mar. Biol. Ecol. 233:65-79.

Stimson, J., and S. T. Larned. 2000. Nitrogen 
efflux from sediments of a subtropical bay and the potential contribution to macroalgal nutrient requirements. J. Exp. Mar. Biol. Ecol. 252:159-180.

Stimson, J., S. Bloom, and R. Brock. 1982. An experimental study of the influence of muraenid eels on reef fish sizes and abundance. Sea Grant Q. (University of Hawai $i$ Sea Grant College Program) 4:1-6.

Stimson, J., S. T. Larned, and E. J. Conklin. 2001. Effects of herbivory, nutrient levels, and introduced algae on the distribution and abundance of the invasive macroalga Dictyosphaeria cavernosa in Kaneohe Bay, Hawai'i. Coral Reefs 19:343-357.
Underwood, A. J. 1994. On beyond BACI: Sampling designs that might reliably detect environmental disturbances. Ecol. Appl. 4:3-15.

Williams, I. D., and N. V. C. Polunin. 2001. Large-scale associations between macroalgal cover and grazer biomass on middepth reefs in the Caribbean. Coral Reefs 19:358-366.

Williams, I. D., N. V. C. Polunin, and V. J. Hendrick. 2001. Limits to grazing by herbivorous fish and the impact of low coral cover on macroalgal abundance on a coral reef in Belize. Mar. Ecol. Prog. Ser. 22: 187-196. 